\title{
TE TUPU O TE RĀKAU: STAGES OF GROWTH OF MĀORI MEDIUM EDUCATION
}

\author{
Georgina Tuari Stewart 1 \\ School of Education, Auckland University of Technology, Auckland, Aotearoa New Zealand \\ Kīmai Tocker \\ Te Kura Toi Tangata-School of Education, University of Waikato, Hamilton, \\ Aotearoa New Zealand
}

\begin{abstract}
Over the past 40 or so years, a small sub-sector of state-funded education has developed in Aotearoa New Zealand, in which the language medium is te reo Māori (the Māori language). Te reo Māori became an endangered language as a result of British colonization and schooling from about 1800 onwards, declining by the mid-1970s to a point where intergenerational transmission had almost completely stopped. Today, Māori medium graduates and their children are growing up as new generations of Māori people, equipped with skills to contribute positively to Māori society and futures and the wider world. The efforts required to support these developments reflect the strong aspirations of Māori people for the survival and restoration of te reo Māori and Māori culture for future generations. This article presents a high-level overview of Māori medium education and its contribution to the revitalization of te reo Māori by focusing on four sequential stages of its growth and evolution: early childhood, school, tertiary, and doctoral studies.
\end{abstract}

Keywords: Kōhanga Reo, Kura Kaupapa Māori, Māori medium education, Te reo Māori, Wānanga

Citation: Stewart, G. T., \& Tocker, K. (2021). Te tupu o te rākau: Stages of Māori medium education. WINHEC: International Journal of Indigenous Education Scholarship, 16(1), pp. 113-141. http://dx.doi.org/10.18357/wj1202120277. Special Issue on Indigenous Language Revitalization: Innovation, Reflection and Future Directions, Guest Co-Editors Drs. Onowa Mclvor and Kari A. B. Chew.

\footnotetext{
${ }^{1}$ Correspondence: Georgina Tuari Stewart, Auckland University of Technology, georgina.stewart@aut.ac.nz
} 


\section{Introduction}

The term "Māori education" has been part of the national educational discourse of Aotearoa New Zealand from its very beginnings, but in recent decades the meaning of "Māori education" has been transformed from the colonizing, assimilatory meaning of "education of Māori" to a new, decolonizing, emancipatory meaning of "education for Māori" in which Māori medium education is central (Durie, 1999).

In the latter part of the twentieth century, Māori education took a new direction in the creation of Te Kōhanga Reo, total immersion Māori language settings for preschool children. Te Kōhanga Reo introduced an educational approach that repositioned Indigenous Māori culture and language as legitimate in provisions now called Māori medium education. (Hohepa \& Paki, 2017, p. 97)

This new direction followed over a century of colonial "education" in which "Māori language and culture were positioned as obstacles to educational progress and denied space in the education system" (Hohepa \& Paki, 2017, p. 96). A recent reversal in the logic of policy discourse for Māori in English medium or "mainstream" education reflects the success of Māori medium education: After a century of blaming te reo Māori for the underachievement

of Māori students in school, contemporary education policy attributes intransigent inequity for Māori learners to the lack of te reo Māori in schools (Durie, 1999). These observations highlight the political nature of Māori medium education in reflecting dominant national thinking and how it changes over time. 
Māori medium education is a complex practice, much more than a "simple" matter of translation (Malmkjær, 2010). Māori medium education harnesses Māori energy and passion for language and culture and yokes these to education policy drivers such as equity, the Treaty of Waitangi, choice, and innovation. Māori medium education is an outstanding success of Māori identity politics in the contemporary post-colonial period and a way for the state to be seen to be "doing the right thing" to deliver equity for Māori in education and protect the future of te reo Māori overall. Te reo Māori is recognised as a leader in the international networks of Indigenous language revitalization. The successes of Māori language revitalization have been closely associated with Māori medium education and social values of tolerance and equality, as expressed in the classic Kiwi slogan of giving everyone a "fair go."

This research looks through the lens of "stages of growth" in order to achieve breadth across the sectors, since most small-scale educational research is confined within one sector. Both authors have lived through the evolving stages of growth of Māori medium education as parents, teachers, teacher educators, and researchers. Both authors are members of the language "hinge" generation: our parents were native Māori speakers who learned English on going to school, and our children were born at a time when Māori medium options had become available (Tocker, 2017). But for Māori people like us, born between about 19501980, the language of home, school, and the public sphere was normatively English. To write this article, we weave together our combined experiences and previous research with critical commentary based on research literature. 
The near loss of the Māori language, which is the embodiment of Māori identity and central in the Māori way of life, was the outcome of over a century of language suppression as part of the assimilationist policies administered by successive governments (Penetito, 2010). National surveys of Māori language use in the 1970s called attention to the moribund state of the language. Richard Benton (1978) reported that there were few remaining native speakers of Māori, and few children could speak the language, so it was fated to die out if drastic measures were not taken to ensure its survival. Benton's report raised the alarm among Māori, who agitated for Māori language recognition in education and law. This period of activism gave rise to new forms of Māori immersion education: Kōhanga Reo at pre-school level and Kura Kaupapa Māori at primary-school level (Nepe, 1991). These Māori-medium learning environments were attempts to preserve and rekindle Māori language and culture and provide a Māori education that validates traditional Māori knowledge and pedagogy: all values that must be struggled for on a daily basis in New Zealand (Olsen-Reeder et al., 2017).

The phrase "kaupapa Māori" denotes a position in which Māori language, values, culture and ways of being are viewed as "normal" and central, therefore giving credence to a Māori world view. A kaupapa Māori stance provided the springboard for the group of Māori pushing at the political level for the right to a Māori language and Māori-centred education for their children. The main aim of Kura Kaupapa Māori is to enable children to "live as Māori." According to Mason Durie (2003, p. 199), the goal of enabling Māori to live as Māori should be an objective of educationists when preparing Māori children for the future. However, the notion of "living as Māori" is a very complex idea, not least because New Zealand is a society 
governed by the English language and a set of values and social structures that are far removed from the traditional world of Māori.

The social results of Māori medium education have encouraged a new high level of national support and acceptance of te reo Māori in Aotearoa New Zealand (Albury, 2016; Stephens, 2014). Language revitalization research is radically interdisciplinary and defies conceptualization; the complete picture is impossible to grasp from one position (Day et al., 2016). For those less familiar with education in Aotearoa New Zealand, the list below summarises the sectors of Māori medium education discussed in this article, with the decade in which each was established shown in brackets. The following four main sections focus in turn on Māori medium education in early childhood, school, tertiary, and doctoral studies, to paint a picture of the growth of the stages of Māori medium education.

\title{
List of Māori Medium Education Sectors/Stages of Growth
}

\author{
Early childhood: Te Kōhanga Reo (1970s) \\ School: $\quad$ Kura Kaupapa Māori (1980s) \\ Wharekura (1990s) \\ Tertiary: $\quad$ Wānanga, for example, Te Wānanga o Awanuiārangi (1990s) \\ Polytechnic courses, for example, Te Wānanga o Ngāpuhi (1990s) \\ Private Training Establishment (PTE), for example, Te Kura Takiura \\ University: Māori Studies as a local discipline (1950s) \\ Māori Initial Teacher Education, for example, Te Huarahi Māori
} (1990s) 


\section{Māori Medium Early Childhood Education: He kākano i ruia mai i Rangiātea}

The decolonial genius of Māori medium education was the creation of early childhood education centres, known as Kōhanga Reo (literally, language nests), in which mostly kuia (female elders) became teachers of mokopuna (Māori infants), speaking only in their first language, te reo Māori: their home language and the birthright of all Māori people. These elders, born before 1945, shared common life experiences of having been forced to become bilingual, learning to speak English on turning five, and going to school (Blank, 1968). That generation had learned to curb their mother tongue, reserving te reo for the marae and private times amongst themselves, speaking only their second language, English, to their children, hoping they could have less traumatic school experiences (Selby, 1999).

The work of the elder teachers of Kōhanga Reo in those early years was politically radical and culturally transformative community language activism that transgressed the norms and rules they had followed for decades (May, 1999). At the collective Māori level and from the theoretical perspective of language policy and planning, the initiation of Kōhanga Reo was a deliberate sociolinguistic strategy to rescue and revitalize te reo Māori, bypassing the lack of te reo fluency of the parents, who were of the urban Māori generations born since 1960 and had grown up without their language (Spolsky, 2003).

Kōhanga reignites intergenerational language and culture transmission processes and enables whānau (family) to pass Māori language on to their tamariki (children) through culturally preferred socialisation practices, even when parents are not fluent speakers. (Hohepa \& Paki, 2017, p. 98) 
Taking a wider view, Te Kōhanga Reo had immense impact on Māori society overall, and hence on Aotearoa New Zealand as a nation (Smith, 1990, 2003), over and above its influence on the mokopuna themselves of the Kōhanga generations. Te reo Māori started to be "ideologically tolerated by the majority" (Albury, 2016, p. 298): Suddenly, it seemed, it became socially acceptable to hear and use Māori in public spaces, including media, arts, sport, law, health, and others (Stephens, 2014).

Kōhanga Reo was more than a language nest. It was more than a childcare centre. Today it has become a social, economic, health, educational, spiritual, political and cultural renaissance for Māori. (Royal Tangaere, 1997, p. 43)

But in 1990, as part of the wide-ranging reconfiguration of the national public service under neoliberal policy influences, control of Kōhanga moved from Māori Affairs, which was abolished, to the newly reconfigured Ministry of Education:

The devolution of the Department of Maori Affairs in 1989 lead to the decision by the Minister of Education and the Minister of Maori Affairs that the newly formed Ministry of Education would be the most appropriate government department to oversee kōhanga reo. The reasoning was that kōhanga reo, like the early childhood sector, would be eligible for funding through the Ministry of Education. (Royal Tangaere, 1997, p. 43)

This change in policy effected a neoliberal state takeover of what had begun as a communityinitiated movement for te reo revitalization. It was a key moment in the history of Māori medium education, and although the early childhood sector continues to embrace a 
"bicultural" narrative, the reality for Kōhanga Reo was the advent of sharp declines, as shown by this summary of national statistics:

The first kōhanga reo opened in 1982. Growth in the number of children that attended continued throughout the 1980s, and peaked in 1993 with over 14,000 enrolments. At this time kōhanga reo were responsible for close to half of all Māori enrolments in early childhood services. By 2001, enrolment numbers had declined to around 9,500, where they remained until 2012. (Statistics New Zealand Tatauranga Aotearoa, 2020)

Today, the decline of Kōhanga Reo seen in the 1990s has slowed, but national numbers are stagnant: 2019 statistics show a total Kōhanga Reo roll of approximately 8,500, a level that has remained steady for the last several years according to Ministry of Education statistics (http://www.educationcounts.govt.nz).

For some years now, Māori medium graduates have been becoming parents and bringing their own children to Kōhanga Reo. This second generation of Māori medium learners contributes to the resumption of inter-generational transmission of Māori language and culture, a key element of language revitalization that was not seen in a 2003 study that reported that " 20 years of activity have produced no more than a handful of new speakers who might be expected to ensure natural intergenerational transmission to their own children" (Spolsky, 2003, p. 569). Fifteen years later, we see growing numbers of Māorispeaking couples and families in the community. A recent statistical report on Māori medium education notes that "with over 60,000 Māori having attended Kōhanga Reo since its 
inception, these institutions continue to play a crucial role in reviving te reo Māori" (Statistics New Zealand Tatauranga Aotearoa, 2020, p. 21).

The proverbial phrase "he kākano i ruia mai i Rangiātea" (a seed sown in the heavens) is used in the section title above to reflect the immense symbolic significance of Kōhanga Reo to the modern Māori renaissance and because the Kōhanga Reo movement sowed the seeds of language regeneration of te reo Māori, which later grew in diverse ways and places that could not have been fully anticipated. Without Kōhanga Reo, the other stages of Māori medium education would not have been able to develop, so Kōhanga Reo is like the mātāmua (first born) of the sectors and hence a leader of Māori medium education.

\section{Māori Medium Schooling: Te Waonui a Tāne}

Tāne is the Māori deity of both humankind and the forest, and "te waonui a Tāne" depicts the verdant growth of Māori children in Māori medium schools: a category that includes all immersion and bilingual school programmes where te reo is spoken at least 50 percent of the time. Kura Kaupapa Māori were legally established in 1989, and legislation also provides for the creation of other "special character" schools. Over time, other types of Māori medium programmes have developed, both whole schools such as Kura Taiao and Kura-a-Iwi, and units within schools, both full immersion and bilingual. Given this diversity in the Māori medium school sector, this section focuses mainly on Kura Kaupapa Māori, the original and largest type of school offering immersion in Māori language and culture across the school span, from Year 1 (mostly 5-year-olds) to Year 13 (mostly 18-year-olds), consisting of a brief statistical snapshot, below, followed by a discussion of its aims and achievements. 


\section{Statistical Snapshot of Kura Kaupapa Māori}

The number of children attending Kura Kaupapa Māori has slowly increased by about 5 percent each year, from 3,226 in 1996 to 8,060 in 2019. Meanwhile, growth in other Māori medium school types such as Kura-a-Iwi (kin group-based schools) and Kura Taiao (environment-focused schools) means that by 2019, these types have combined student numbers nearly equal to those of Kura Kaupapa Māori. The number of students in bilingual programmes has remained steady at around 4,000, adding up to the total of 21,489 students reported in Māori medium schooling, which corresponds to 11 percent of the Māori roll, and 3 percent of the total school roll. The table below compares the relative sizes of the national roll in the first and last years of school, Year 1 and Year 13, for three cohorts: all students, all Māori students, and all Kura Kaupapa Māori students (http://www.educationcounts.govt.nz).

\section{Comparing National, Māori, and Kura Kaupapa Māori Rolls at Year 1 and Year 13}

$\begin{array}{llll}\text { 2019 School Roll Statistics } & \text { Year 1 } & \text { Year 13 } & \begin{array}{l}\text { Attrition: } \\ \mathbf{1 0 0 - ( Y 1 3 / Y 1 ) \% ~}\end{array} \\ \text { National total roll } & 61,517 & 47,599 & 23 \% \\ \text { Māori roll (\% of national) } & 15,375(25 \%) & 8,232(17 \%) & 46 \% \\ \text { Kura Kaupapa Māori roll } & & & 74 \% \\ \text { (\% of Māori roll) } & 834(5 \%) & 218(3 \%) & \end{array}$

These data reveal two concerning trends: First, about half of all Māori students are no longer in school by Year 13, a much higher rate of attrition than for all students; and second, around three-quarters of students who enter Kura Kaupapa Māori at Year 1 leave before completing 
Year 13, with many migrating to English medium schools during their secondary (high) school years.

Schooling in Aotearoa New Zealand is compulsory, whereas early childhood and tertiary forms of education are non-compulsory: a crucial distinction in terms of policy and the "bottom line" of the state's commitment to fund Māori medium schooling as part of the legal language rights of Māori people in Aotearoa New Zealand. This basic difference between compulsion and choice impacts on all aspects of development of Māori medium education in the various sectors and the strategies open to them in negotiations with the state.

\section{Aims and Achievements of Kura Kaupapa Mãori}

Kura Kaupapa Māori provide an education system in which primary (elementary) school children are immersed in the Māori language and culture. In its goal to enable children to live as Māori, this unique Māori immersion learning environment fosters the educational growth of bilingual, bicultural children. Kura Kaupapa Māori aims to create adults who will strive to attain academic achievement while carrying Māori language and knowledge. There is also an expectation that children will be taught the skills and knowledge that will enable them to adapt and live at ease in a variety of situations domestically and globally, for it is crucial that Māori students are well-prepared to advance into the world and the international domain as active and contributing citizens.

During Kura Kaupapa Māori schooling, students learn facets of Māori ways of behaving that help them in later life as adults. The practice of standing to deliver a mihi (greetings) or 
whaikōrero (speech), and to perform waiata (song) and haka (type of dance) helps the young people to gain confidence in their abilities to address large groups of people. The Māori immersion, whānau-oriented education in Kura Kaupapa Māori instills confidence in the graduates and a sense that they have the ability to enter any kind of work. Kura Kaupapa Māori graduates have no difficulty in finding employment. Armed with the Māori language, a strong identity, and a sense of being able to achieve whatever they aspire to, early graduates were employed in Māori media and Māori medium teaching. Others from the first cohorts of graduates from Māori medium education undertook university study; one became a doctor, another a psychologist (Tocker, 2014).

The graduates provide insight into how Māori medium education has provided guidance and support in their lives. Upon their graduation from school, it has been the maintenance of Māori language and values that has given them the strength and mechanisms to cope in a world that is often at odds with the Māori worldview that nourished them during their schooling. In upholding values such as manaakitanga, whanaungatanga, and aroha, the graduates give life to traditional Māori cultural practices and Māori tikanga and, in the modern contexts of kapa haka groups, sports clubs, and social venues, have a sense of being wherein it is normal to be Māori.

With their knowledge of te reo Māori and tikanga, the graduates are aware of their responsibilities towards whānau, hapū, and iwi and the expectations of possible leadership roles in the future for their people. Thus, they exemplify the vision of those who gave birth to Kura Kaupapa Māori and Te Aho Matua. 
In utilising the value of whanaungatanga, Kura Kaupapa Māori graduates nourish a strong connection to the kura whānau and to their own kura friends and classmates. The bond and identification to Kura Kaupapa Māori is about identity. Graduates proudly identify as exstudents of Kura Kaupapa Māori and wharekura (secondary forms of Kura Kaupapa Māori) and most importantly, see each other as family. The elements of manaakitanga and aroha (love, respect, and understanding) are embodied by the graduates in their lived experiences of tikanga Māori. The concept of whanaungatanga (relationships) is crucial in te ao Māori, where whanaungatanga refers to relationships informed by whakapapa (Mead, 2016), which literally means genealogy, but also has additional, deeper meanings. The whakapapa that binds the Kura Kaupapa Māori graduates is made up of their shared experiences at school. The graduates in Auckland are a whānau (extended family) who socialise and play sport together and have formed a renowned kapa haka group. Some have marrried and now have their own children growing up in a kaupapa Māori environment (Tocker, 2014).

The graduates of Kura Kaupapa Māori are strikingly different from most of the previous generations of Mãori school leavers, as described in a story that hits precisely the link between education, equity, and Māori-Pākehā social relations, told by Iritana Tawhiwhirangi, a founder of the Kōhanga Reo movement:

Those children who did not succeed left the education system disillusioned and angry. Many joined gangs, became "antisocial" and rejected society. Of the small percentage of Maori children who succeeded many went to university but many still left the education system-disillusioned and angry. This was the start of the Nga Tamatoa (a vocal university-based Maori political movement). The two 
groups left the education system-disillusioned and angry. One group were able to articulate their anger while the other physically demonstrated their anger. One group were able to critically analyse government policies and identify the inequity. The other group were barely literate. (as recounted in Royal Tangaere, 1997, p. 41)

Through the practice of whanaungatanga and the maintenance of Māori language and cultural values, the graduates are normalising the use of Māori language and ways of being outside of traditional Māori domains. In adhering to Māori values, the graduates know that they must take care of the taonga (treasures) of the Māori language, culture, and traditions acquired through their education; there is a cultural expectation for them to return to their homelands and share their Māori knowledge with their own communities. Armed with this knowledge and understanding and a strong identity and self-belief, a number of graduates have become leaders in their professions and are not afraid to put forward viewpoints that represent a Māori worldview to New Zealand society and challenge its predominance of Western values and ideologies.

\section{Māori Medium Tertiary Education: Te Tihi o te Maunga}

The 1998 Hawke report on the tertiary sector "advocated the decentralisation of postcompulsory education and training, and also recognition of Māori claims to education under the 'principles of the Treaty of Waitangi'" (Walker, 2005, p. 4). Decentralisation was implemented and led to the current tertiary scene, made up of four sub-sectors: universities,

polytechnics, private training establishments (PTEs), and Wānanga; but universities struggle 
to respond to the challenge of "Māori claims to education" as seen by the debates about incorporating Māori/Indigenous knowledge in the university (see, for example, Cram et al., 2014). Māori participation in tertiary education overall remains limited in terms of proportionate number of students and skewed in terms of being concentrated in restricted areas of study, mostly pre-degree level te reo (Māori language) or tikanga-based courses (Earle, 2007). In 1997, it was found that "there were few courses available at the tertiary level taught through the medium of Māori other than some teacher training courses and Māori language courses" (Durie, 1999, pp. 74-75), and this finding is still relevant in 2021. Nevertheless, Māori medium education has infiltrated all four forms of tertiary in different ways and extents, resulting in an extremely complex picture. What follows is a brief sketch, first giving examples of Māori medium education in polytechnics and PTEs, then more extended discussion of Māori medium education in Wānanga and universities.

Most polytechnic education is at pre-degree level, with one relevant example from NorthTec based in Whāngarei, which has taught certificates and diplomas of regional Māori language and knowledge for 25+ years (http://www.northtec.ac.nz/programmes/te-reo). The diploma level courses include spoken and written Māori medium assessments and integrate language learning with history, iwi politics, research skills, and marae leadership roles. Such programmes highlight the overlap between "learning of the language" and "learning in the language" (Earle, 2007, p. 2). These two orientations cannot be seen as entirely separate and defy analytical and funding categories. This fuzzy overlap is inherent in all tertiary Māori medium education and is a key aspect of its complexity. 
Private Training Establishments are privately-owned businesses that generally offer industry-specific training. Accredited courses and their students receive government funding. Te Wānanga Takiura o ngā Kura Kaupapa Māori o Aotearoa (http://www.twt.ac.nz) is a PTE based in Auckland that offers Māori medium initial teacher education and te reo Māori courses, as one significant example of Māori medium education in the PTE sub-sector of tertiary education.

The Wānanga sector comprises three Māori tertiary institutions established by 1990 legislation that marked success following a long struggle by, among others, Whatarangi Winiata (as recounted in Walker, 2005). Wānanga are structurally Māori institutions, so, in this sense, are the tertiary equivalent of Kōhanga Reo and Kura Kaupapa Māori. Each Wānanga has distinctive characteristics, but in relation to meeting the criteria of the New Zealand Qualifications Authority (NZQA) and fitting within the systems of funding, all face "a problem arising out of their special character regarding 'āhuatanga Māori"' (Walker, 2005, p. 7, emphasis in original). The problem arises from "extension of the field into iwi/hapū (tribal) studies and whakapapa (Māori epistemology, equivalent to Foucault's genealogy of knowledge)" (p. 7) and is exacerbated by proposals written in te reo, "complete with cultural values such as wairua, (spirituality) aroha, (love, compassion) whanaungatanga (kinship, relationships) and manaaki (care for, support, hospitality)" (Walker, 2005, p. 8). One empirical study of adult literacy provision in a Wānanga discovered this problem, describing the Wānanga as needing to navigate the tensions created when "major but contrasting policy goals such as Māori particularism and economic universalism are simultaneously pursued" 
(Zepke, 2011, p. 440). These wording choices and terms showcase the philosophical nature of the problem, which therefore logically cannot be resolved by technical solutions.

The phrase "te tihi o te maunga" means "the top of the mountain," with reference to the Māori metaphor of achievement as climbing uphill, which evokes the academic pathway of graduates of Māori medium schooling who proceed to university as young adults. The significance of Māori medium university education can be apprehended only by comparison with the previous century or more of deliberate strategies to lock te reo Māori outside the university gates (Durie, 1996; Walker, 1999). In 2021, Māori medium university education remains restricted to departments of Māori studies and degrees in initial teacher education (Lee-Morgan et al., 2019; Stewart et al., 2018), as was noted in 1999. The idea of teaching a "full undergraduate degree programme through the medium of Māori" (Durie, 1999, p. 75) remains hypothetical and looks set to be so for the foreseeable future. The workaround has been to adopt a fairly uniform policy in all eight universities that gives students the right to submit work written in te reo for any assignment, with provisos regarding the language fluency of the student and the ability of the department concerned to make appropriate marking arrangements.

For graduates of Kura Kaupapa Māori who have grown up all their lives in Māori culture and language, arriving at university is a major culture shock, daunting yet exciting (Stewart, 2018). Te reo Māori is their "safe" mode, their natural language of communication, and they carry it with them, as shown in these quotes from graduates: 
Sometimes I actually - there were a few assignments where I would write it in Māori and try and translate it. (Reported in Stewart, 2018, p. 11)

There was no question of which language do you choose. When I started varsity in the Māori department as soon as I found out that they took assignments in te reo I was like, great, I'm writing in that. (Reported in Stewart, 2018, p. 12)

To use te reo at university is a legal right, given the official language status of te reo Māori (May, 2012). Writing in te reo at university is a strategic deployment of the power of the written word in the politics of Māori language revitalization and mana motuhake (Māori rights) under the broader intellectual project of kaupapa Māori. Thus, Māori medium university education is a form of epistemological "border work" that deals in the liminal space of the no-man's-land between cultures and languages: the abysses and bridges that separate and traverse European and Indigenous knowledge forms and bases (Andreotti et al., 2011).

\section{Māori Medium Doctoral Graduates: Ngā Raukura Kairangi}

The first doctoral degree for a thesis written wholly in te reo Māori was awarded in 2000 (Black, 2000); in 2020 there were a total of 20 Māori medium doctoral graduates, from five of the eight universities in Aotearoa New Zealand (Stewart, 2019). As well as the eight universities, there is a ninth doctoral awarding institution, Te Wānanga o Awanuiārangi, where it is normal to write assignments in te reo Māori. 
The first Māori medium doctoral completion by a graduate of the Kura Kaupapa Māori school system was recorded in 2010 (Mahuta, 2010). Two further Kura Kaupapa Māori graduates reached this achievement in 2013 (Martin, 2013) and 2015 (Poutū, 2015). Among the graduates of Kura Kaupapa Māori are numerous academic success stories, including some who have graduated with doctoral degrees written in English and many who have completed undergraduate and postgraduate qualifications. Every doctoral completion is a taonga to the graduate and their whānau and iwi. But it is difficult to overstate the symbolic success for the Kura Kaupapa Māori movement and Māori medium education more generally, of the achievement of these three special raukura kairangi (doctoral graduates) who have gone all the way through the formal education system, from pre-school to doctoral thesis, entirely in te reo Māori. “The years of commitment you make as a parent, it's worth it when they can go all the way to do whatever they want, and the language is there alongside them" (a Māori professor, quoted in Stewart, 2019, p. 82).

A doctoral thesis is a theorization of a field of practice, so it makes sense that all the Māori medium doctoral theses written to date are in Māori Studies and Māori Education, which are the main fields of existing Māori medium practice. In future, Māori medium doctoral theses are likely to appear in fields where a Māori practice has begun, such as architecture, the arts, environmental science, health sciences, literature, media studies, and psychology. Better national coordination would be beneficial for all those involved in Māori medium doctoral studies as supervisors and senior managers. Universities cannot control future decisions by students about writing doctoral theses in te reo, but could be proactive in developing systems to support future initiatives. The most important steps a university can take to encourage 
Māori medium doctoral studies are to have appropriate systems in place that can be flexible while upholding academic standards and are underpinned by a welcoming attitude towards Māori language and culture.

\section{Conclusion: Ngā Hua o te Kaupapa}

The word "hua" literally means "fruit"-also commonly used to mean "outcomes" or "children/descendants" as in the "fruits of one's labour/loins." "Ngā hua o te kaupapa" refers to the achievements of decades of lifework by many Māori people in tending the growth of the fruits of the tree of Māori medium education. These fruits include the systems and structures, physical and discursive, that have grown around the obstacles as best they could, resisting the winds of policy and funding changes. The ends of all that effort are the most important fruits of the kaupapa: those human beings who have grown up and become magnificent, now carrying the kaupapa forward into the future. In conclusion, four whakatauki (proverbial sayings) are used below to introduce four key themes or insights concerning the current status of the Māori medium education system. These inspirational proverbs are widely heard in the Māori medium education community and some have already appeared in titles, above. They are all reflected in the underlying philosophy of the kaupapa Māori approach in education (Stewart, 2020).

\section{He tangata i àkona ki te whare, tūnga ki te marae tau ana}

A person who is taught well at home can operate confidently in the outside world. This whakataukī represents how Māori medium education prepares graduates to achieve highly in both the Māori world and the wider world. The adult graduates of Māori medium education, especially those who have grown up in Kōhanga Reo, Kura Kaupapa Māori, and Wharekura, 
are achieving across many societal domains, educational and otherwise, while also repopulating the community leadership positions of the marae and iwi around the country. Māori medium education has not hampered the achievement of graduates in the wider English-speaking world.

\section{E kore ahau e ngaro, he kākano i ruia mai i Rangiātea}

I will never be lost, for I am a seed sown from the celestial realms of Rangiātea. This whakatauki recalls the unbroken thread of language and culture from past, to present, to future, and the vital importance of te reo Māori to the goal of living as Māori. Māori medium education is one significant part of a larger story of the revitalization of te reo. This whakataukī speaks to the contributions of the stages of Māori medium education, and above all to the power of grandmothers talking to infants in Kōhanga Reo, an act of grace that seeded the renewal of intergenerational Māori language transmission.

\section{Te piko o te māhuri, tērā te tupu o te rākau}

As the sapling bends, so the tree grows. Māori medium education has developed and grown in different ways at each stage, according to the context and its affordances, opportunities and challenges. Māori medium education develops within a wider social environment that both supports and obstructs its success. Māori medium schooling supported and was supported by the concurrent growth of Māori television, radio, and print media and by the expansion of kaupapa Māori initiatives into other domains beyond education. These became career pathways for Māori medium graduates, in addition to Māori medium teaching and Māori language translation services. New technologies such as digital publishing and the 
ubiquitous ability to record and share video footage change language norms in ways not yet fully understood. Māori medium education and the te reo movement is well positioned to take up the opportunities offered by the post-digital age of education (Reader et al., 2020).

One example of the wider effects of Māori medium education is the regeneration of the town of Ōtaki, on the west coast of the North Island, about an hour's drive north of Wellington. This was the site of the efforts by Winiata, mentioned above, to establish a strategic plan to regenerate te reo and culture among his people, with Māori medium education playing a key role. This story of social reclamation is told by Mereana Selby (2016), who has been integral in its success.

\section{Whāia te iti kahurangi, ki te tūohu koe me he maunga teitei}

Strive for the highest peak of achievement; if you should bow your head, let it be to a lofty mountain. Against the odds, and overcoming many difficult challenges, three students, who began learning as infants in the early years of Kōhanga Reo, kept going all the way through Kura Kaupapa Māori for their primary, intermediate, and secondary schooling, then on to university and undergraduate, postgraduate, and finally doctoral studies, writing and defending their doctoral theses in te reo Māori. The significance of their achievement cannot be overestimated. As well as the immense value to the graduates, their family, iwi, and peer groups, and as models for others to follow, this result crowns the success of Māori medium education by demonstrating the possibility of growing an entire system of immersion education in the medium of an endangered Indigenous language, from early childhood to doctoral studies, in one generation. 


\section{Glossary of Māori Words (as used in this article)}

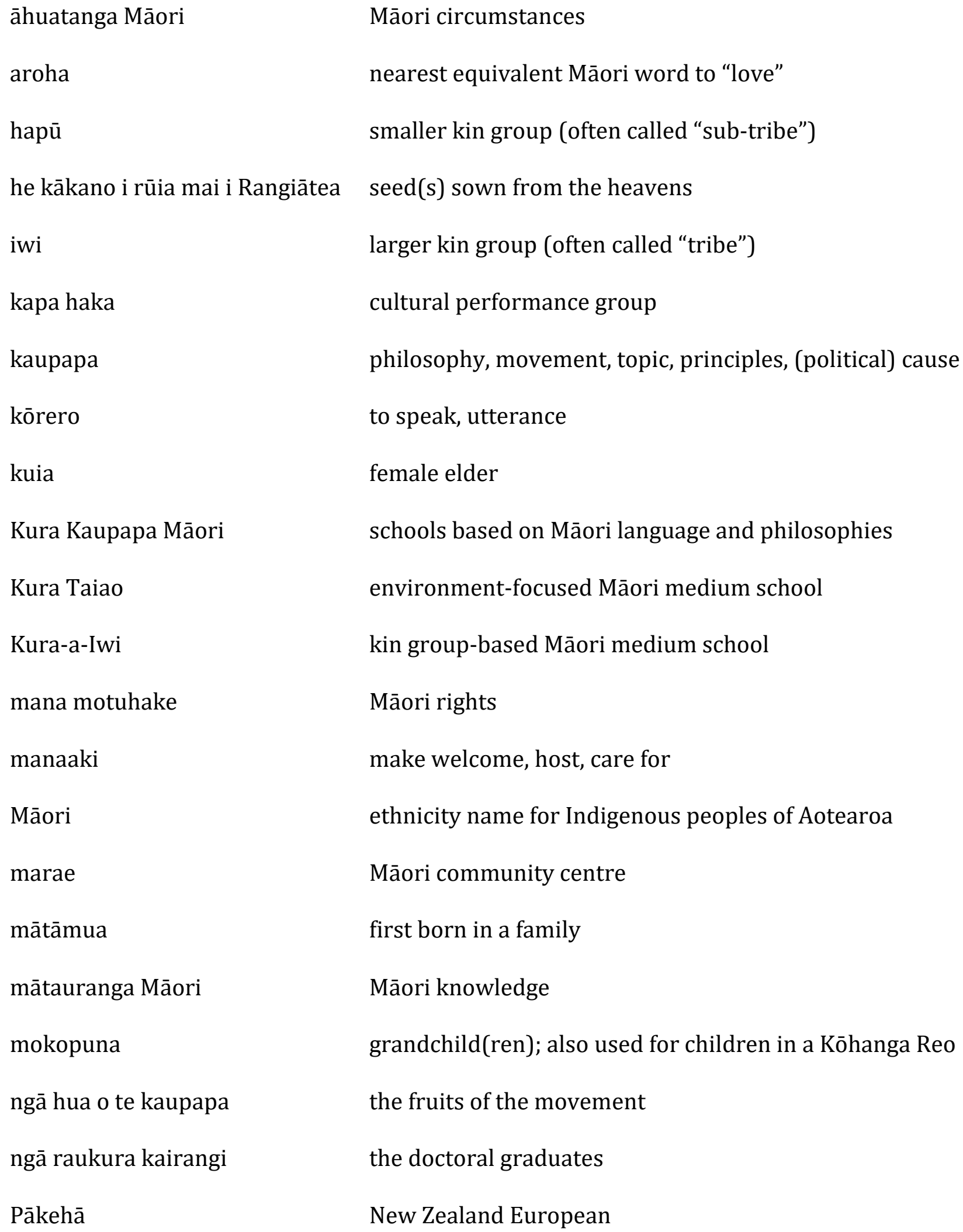




\begin{tabular}{|c|c|}
\hline tamariki & children \\
\hline taonga & treasure, valuable \\
\hline \multirow[t]{2}{*}{ Te Kōhanga Reo } & Māori medium early childhood education, lit. "language \\
\hline & nest" \\
\hline te reo Māori & the Māori language \\
\hline te tihi o te maunga & the peak of the hill \\
\hline te tupu o te rākau & the growth of the tree \\
\hline te waonui a Tāne & the forest of Tāne \\
\hline wairua & spirituality \\
\hline Wānanga & Māori form of tertiary institution \\
\hline whakapapa & nearest equivalent Māori word to "genealogy" \\
\hline whakataukī & proverbial saying \\
\hline whānau & family, wider family, also used for a school community \\
\hline whanaungatanga & relationships \\
\hline wharekura & secondary (high-school level) Kura Kaupapa Māori \\
\hline
\end{tabular}




\section{About the Authors}

Georgina Tuari Stewart (ORCID: 0000-0001-8832-2415). Ngāti Kura, Ngāpuhi-nui-tonu, and Ngāti Whanaunga, Pare Hauraki. Has a background in Māori medium science teaching; interested in biculturalism and Indigenous research methodologies. Recently completed a Marsden funded research project investigating Māori medium doctoral theses. New book: Mãori Philosophy: Indigenous Thinking from Aotearoa (Bloomsbury, 2020).

Kìmai Tocker (ORCID: 0000-0001-8668-8771). Ngāti Tūwharetoa, Ngāti Raukawa, Ngāti Maniapoto and Waikato. A lecturer in Te Kura Toi Tangata-School of Education at the University of Waikato in Hamilton. Kīmai's interests include Māori medium education and Kura Kaupapa Māori. She is working on a narrative approach in collecting stories about Māori experiences in education across generations. 


\section{References}

Albury, N. J. (2016). Defining Māori language revitalisation: A project in folk linguistics. Journal of Sociology, 20(3), 287-311.

Andreotti, V., Ahenakew, C., \& Cooper, G. (2011). Epistemological pluralism: Ethical and pedagogical challenges in higher education. AlterNative, 7(1), 40-50.

Benton, R. (1978). Can the Maori language survive? New Zealand Council for Educational Research.

Black, T. (2000). Kāore te aroha... te hua o te wānanga [Doctoral dissertation, Massey University]. https://mro.massey.ac.nz/handle/10179/1117

Blank, A. (1968). One two three four five. In E. Schwimmer (Ed.), The Mãori people in the 1960s (pp. 84-96). Longman Paul.

Cram, F., Phillips, H., Sauni, P., \& Tuagalu, C. (Eds.). (2014). Māori and Pasifika higher education horizons. Emerald Group.

Day, D., Rewi, P., \& Higgins, R. (Eds.). (2016). The journeys of besieged languages. Cambridge Scholars Publishing Ltd.

Durie, A. (1999). Emancipatory Māori education: Speaking from the heart. In S. May (Ed.), Indigenous community-based education (pp. 67-78). Multilingual Matters.

Durie, M. H. (1996). The development of Māori studies in New Zealand universities. He Pukenga Kōrero, 2(1), 21-32.

Durie, M. H. (2003). Ngā Kāhui Pou launching Mãori futures. Huia Publishers.

Earle, D. (2007). He tini manu reo: Learning te reo Mãori through tertiary education. https://www.educationcounts.govt.nz/publications/80898/9897

Hohepa, M., \& Paki, V. (2017). Māori medium education and transition to school. In N. Ballam, B. Perry, \& A. Garpelin (Eds.), Pedagogies of educational transitions: European and Antipodean research (pp. 95-111). Springer Nature. https://doi.org/10.1007/978-3-319-43118-5_7

Lee-Morgan, J., Courtney, M., \& Muller, M. (2019, 2019/03/15). New Zealand Māori-medium teacher education: An examination of students' academic confidence and preparedness. Asia-Pacific Journal of Teacher Education, 47(2), 137-151. https://doi.org/10.1080/1359866X.2018.1539214 
Mahuta, D. P. S. (2010). Ko te awa tōku piringa ka puta, ka ora - he tangata, he whenua, he tangata whenua [Doctoral dissertation, Auckland University of Technology]. https://openrepository.aut.ac.nz/handle/10292/1022

Malmkjær, K. (2010). The nature, place and role of a philosophy of translation in translation studies. In A. Fawcett \& R. H. Parker (Eds.), Continuum studies in translation: Translation: Theory and practice in dialogue (pp. 201-218). Bloomsbury Books.

Martin, J. (2013). He kura-hāpainga, he kura-waka, he kura-kōrero, he kura-huna, he kurakura [Doctoral dissertation, Auckland University of Technology], https://openrepository.aut.ac.nz/handle/10292/7470

May, S. (Ed.). (1999). Indigenous community-based education. Multilingual Matters.

May, S. (2012). Language \& minority rights: Ethnicity, nationalism and the politics of language (2nd ed.). Routledge.

Mead, H. M. (2016). Tikanga Māori: Living by Māori values (Rev. ed.). Huia Publishers.

Nepe, T. (1991). E hao nei e tenei reanga: Te toi huarewa tipuna, kaupapa Mãori, an educational intervention system [Master's thesis, University of Auckland].

Olsen-Reeder, V., Hutchings, J., \& Higgins, R. (Eds.). (2017). Te ahu o te reo Mãori. Victoria University Press.

Penetito, W. (2010). What's Māori about Māori education? Victoria University Press.

Poutū, H. N. (2015). Kia Tiori ngā Pīpī: Mā te aha e kōrero Māori ai ngā taitamariki o ngā wharekura o Te Aho Matua? [Doctoral dissertation, Massey University]. https://mro.massey.ac.nz/handle/10179/7402

Reader, J., Jandrić, P., Peters, M. A., Barnett, R., Garbowski, M., Lipińska, V., Rider, S., Bhatt, I., Clarke, A., Hashemi, M., Bevan, A., Trozzo, E., MacKenzie, A., Aldern, J. J., Matias, C. E., Stewart, G. T., Mika, C., McLaren, P., Fawns, ... Baker, C. (2020). Enchantment disenchantment-re-enchantment: Postdigital relationships between science, philosophy, and religion. Postdigital Science and Education. https://doi.org/10.1007/s42438-020-00133-4

Royal Tangaere, A. (1997). Te Kohanga Reo: More than a language nest. Early Childhood Folio, 3, 41-47.

Selby, M. (2016). The road to reclamation: The story of Ōtaki. In D. Day, P. Rewi, \& R. Higgins (Eds.), The journeys of besieged languages (pp. 79-93). Cambridge Scholars Publishing.

Selby, R. (1999). Still being punished. Huia Publishers. 
Smith, G. H. (1990). The politics of reforming Maori education: The transforming potential of Kura Kaupapa Maori. In H. Lauder \& C. Wylie (Eds.), Towards successful schooling (pp. 73-87). Falmer Press.

Smith, G. H. (2003). Kaupapa Māori theory: Theorizing Indigenous transformation of education and schooling. http://www.aare.edu.au/data/publications/2003/pih03342.pdf

Spolsky, B. (2003). Reassessing Māori regeneration. Language in Society, 32, 553-578.

Statistics New Zealand Tatauranga Aotearoa. (2020). Ka mārō te aho tapu, ka tau te korowai: Te reo Māori findings from Te Kupenga 2013.

https://www.stats.govt.nz/reports/ka-maro-te-aho-tapu-ka-tau-te-korowai-te-reomaori-findings-from-te-kupenga-2013

Stephens, M. (2014). A house with many rooms: Rediscovering Māori as a civic language in the wake of the Māori language act (1987). In R. Higgins, P. Rewi, \& V. Olsen-Reeder (Eds.), The value of the Mãori language - te hua o te reo Māori (pp. 53-84). Huia Publishers.

Stewart, G. (2018). Writing in te reo at university. Kōtuitui: New Zealand Journal of Social Sciences Online. https://doi.org/10.1080/1177083X.2017.1418399

Stewart, G. (2019). He iti, he pounamu: Doctoral theses written in Māori. MAI Journal, 8(1), 77-90. https://doi.org/10.20507/MAIJournal.2019.8.1.6

Stewart, G., Trinick, T., \& Dale, H. (2018). Huarahi Māori: Two decades of Indigenous teacher education at the University of Auckland. In P. Whitinui, C. Rodríguez de France, \& O. McIvor (Eds.), Promising practices in Indigenous teacher education (pp. 149-162). Springer Education. http://www.springer.com/gp/book/9789811063992

Stewart, G. T. (2020). Māori philosophy: Indigenous thinking from Aotearoa. Bloomsbury.

Tocker, K. (2014). Hei oranga Māori i te ao hurihuri nei. Living as Māori in the world today: An account of kura kaupapa Mãori [Doctoral dissertation, University of Auckland].

Tocker, K. (2017). Living and learning as Māori: Language stories from three generations. The Australian Journal of Indigenous Education, 46(1), 115-125. https://doi.org/10.1017/jie.2016.28

Walker, R. (1999). The development of Māori Studies in tertiary education in Aotearoa/New Zealand. In M. A. Peters (Ed.), After the disciplines: The emergence of cultural studies (pp. 187-198). Bergin \& Garvey.

Walker, R. (2005). Quality assurance in tertiary education from a Māori (Indigenous) 
perspective. WINHEC: International Journal of Indigenous Education Scholarship, (1), 28-37. https://journals.uvic.ca/index.php/winhec/article/view/19253

Zepke, N. (2011, 2011/07/01). Navigating between Māori particularism and economic universalism in adult literacy provision in Aotearoa New Zealand: The case of a Wānanga. Discourse: Studies in the Cultural Politics of Education, 32(3), 431-442. https://doi.org/10.1080/01596306.2011.573259 